\title{
Seasonal Changes in Water Quality as Affected by Water Level Fluctuations in Lake Tonle Sap, Cambodia
}

\section{OYAGI Hideo*, ENDOH Shuichi, ISHIKAWA Toshiyuki**, OKUMURA Yasuaki and TSUKAWAKI Shinji***}

\author{
* Nihon University; 3-25-40 Sakurajosui, Setagaya, Tokyo 156-8550, Japan. \\ ** Shiga University; 2-5-1 Hiratsu, Otsu, Shiga 520-0862, Japan. \\ *** Kanazawa University; Kakuma, Kanazawa, Ishikawa 920-1192, Japan. \\ E-mail: oyagi.hideo@nihon-u.ac.jp*
}

Received January 27, 2017; Accepted September 1, 2017

\begin{abstract}
Lake Tonle Sap has the largest surface area of any lake in Southeast Asia. The lake's water level varied by $8 \mathrm{~m}$ between seasons in 2005, which resulted in dramatic seasonal changes in the surface area. The quality of the lake water can be divided into two contrasting types in the low- and high-water-level periods. Measurements of water quality were made during the low-water-level period. $\mathrm{Na}-\mathrm{HCO}_{3}$ type water was a characteristic feature of the water quality in the foreshore areas from March to May of 2005. Of particular interest during the low-water-level period is the ratio of chloride ions to total dissolved solids. Changes in the quality of the lake water during low-water-level periods are caused in part by an increase in the influence of discharge from inflowing tributaries as the volume of lake water decreases. In addition, seasonal changes are caused by anthropogenic contamination from mobile villages of floating and folding houses situated around the lake margin. In contrast to the low-water-level period, the dominant composition during the high-water-level period was $\mathrm{Ca}-\mathrm{HCO}_{3}$ type water. The water quality of the lake during the rainy season does not appear to be affected by human activity but is significantly affected by reverse inflow from the Mekong River to Lake Tonle Sap.
\end{abstract}

Key words water level, water quality, monsoon climate, Lake Tonle Sap, seasonal change

\section{Introduction}

Central Cambodia's Lake Tonle Sap is the largest lake on the Indochinese Peninsula. This lake is famously referred to as the "elastic water world" (Lao 1992) because its surface area expands dramatically in the rainy season owing to the substantial supply of water from the Mekong River. It is also referred to as "the heart of Cambodia" due to its diverse range of freshwater organisms. Lake Tonle Sap is known for its unusual aquatic environment, which experiences large changes in the water level and surface area between seasons. According to Sarkkula et al. (2005), the water depth of Lake Tonle Sap varies by approximately $10 \mathrm{~m}$ between the rainy and dry seasons and the lake surface expands and contracts across vast floodplains that consist primarily of forests, shrubs, and rice fields. When the water level in the Mekong River rises during the southwest monsoon, the Tonle Sap River reverses its course and water from the Mekong River flows into the lake. In the dry season, the water depth of the center of the lake drops to approximately $0.7 \mathrm{~m}$ (Figure 1).

This variation is caused by a hydrological phenomenon unique to the Mekong River. Lake Tonle Sap acts as a natural floodwater reservoir for the Mekong system thereby reducing the threat of catastrophic flooding. Consequently, it is important to understand the temporal changes in its hydrological characteristics to establish a water management strategy in the Mekong River Basin. The collection and analysis of fundamental data of the physicochemical characteristics of the lake are also essential to understand seasonal variations in the water quality and the effects of human activities on the lake.

This paper reports an investigation into the changes in the water quality that occur as a result of seasonal changes in the water level. Even though several studies have examined the water quality in Lake Tonle Sap (Lao 1992), little research has been undertaken with regards to its electrical conductivity and $\mathrm{pH}$ in the dry season. Changes in the water quality related to the seasons are affected not only by inputs from the Mekong River but also by the inflow of water from tributaries due to precipitation in the basin, which in turn is affected by the geology, topography, and vegetation cover.

With respect to research on lakes that exhibit significant changes in water level, most investigations have been conducted in brackish lakes or large lakes with a clear 


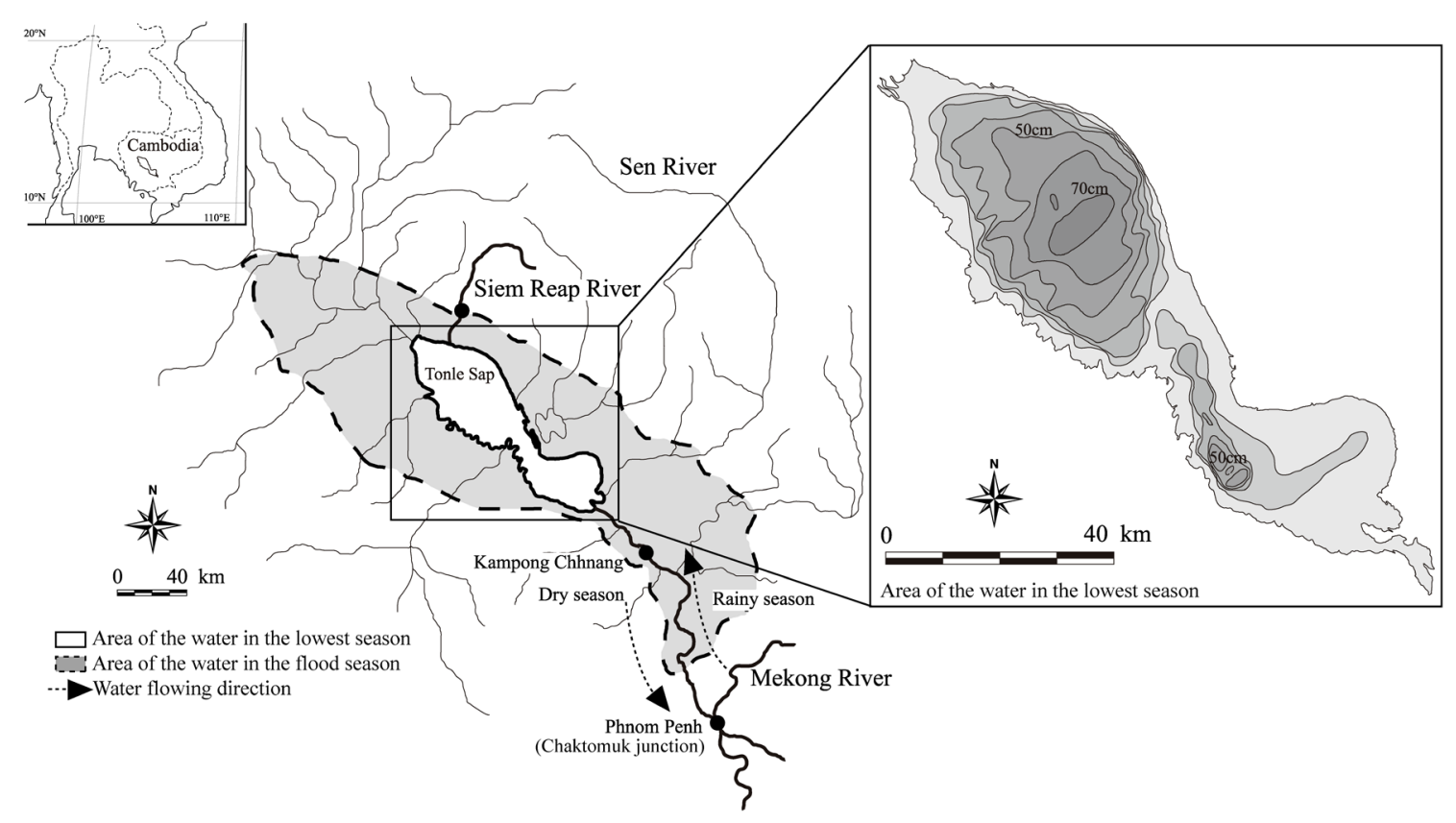

Figure 1. The river network around Lake Tonle Sap and the bathymetric map of Lake Tonle Sap (redrawn from Tsukawaki et al. 1994).

division in conditions between the rainy and dry seasons. Changes in the water levels of brackish lakes are caused by tidal amplitudes. The characteristics of the water quality of these lakes are determined by differences in the density and composition of mixtures of seawater and freshwater (e.g., Mori 1975). By contrast, freshwater systems experience little difference in density and the factors that affect the characteristics of the water quality under seasonal changes in the water level require further study. In addition, many large lakes that exhibit significant changes in water level and surface area, such as Lake Eyre in Australia, lose outlets during the drying phase, which results in dramatic fluctuations in response to variations in the rainfall. In the case of the Aral Sea, the water volume in the lake basin has been reduced in recent years owing to long-term climate change and increases in irrigation. Several studies have been conducted on the changes in the salinity of these lakes via the examination of salt concentrations (e.g., Charles 1982; Max and Colette 1990: 363-364).

Few scientific studies have been undertaken on lakes in monsoonal regions that experience seasonal changes in water level and surface area. This is primarily because relatively few large lakes are located in tropical regions. Furthermore, scientific research has not advanced rapidly, due in part to political problems in Southeast Asia. Lake Tonle Sap is a very important source of water for the Mekong Delta during the dry season because it provides a stable supply of water to support agricultural production. Lake Tonle Sap is one of Cambodia's most important natural resources. The lake has close relationships not only with the diverse biota it contains but also with the society, culture, and life of the Cambodian people. The majority of the Cambodian population lives within the central floodplain of the Tonle Sap and Mekong Rivers, and well over one million people rely upon Lake Tonle Sap's fisheries for their livelihoods, with more than $60 \%$ of the animal protein consumed in Cambodia sourced from the lake. The Tonle Sap ecosystem is believed to be one of the most productive inland waters, as well as one of the most abundant in fish, in the world (Ishikawa et al. 2005).

Studies on the sustainable use of freshwater are indispensable for the preservation of aquatic environments for both water resources and ecosystem needs. In recent years, several development schemes have been carried out in countries outside Cambodia. However, Campbell et al. (2006) indicated that the development of hydropower schemes on the Mekong River in countries upstream of Cambodia presents a real and present danger to the ecosystems and fisheries of Lake Tonle Sap. Sustainable water management and use rely on knowledge of water volumes and water quality with respect to the hydrological cycle. Lake Tonle Sap is known for its exceptional aquatic environment, with huge changes in the lake's area and depth between different seasons.

There is a slight non-metallic white clay and clay for cement in the basin, and the mineral resources are scarce. According to Oyagi et al. (2014), the electrical conductivity of the upstream area of the Siem Reap River is approximately $2.0 \mathrm{mS} \mathrm{m}^{-1}$; this value indicates that almost no 
ions are dissolved in the water. However, it is reported that the water quality, e.g., the $\mathrm{Ca}^{2+}$ and $\mathrm{Mg}^{2+}$ values, of the water flowing from the Mekong River into Tonle Sap Lake is higher than the average value of the general river water quality in Japan (Hori 1996). Studies on the water quality around the lake are somewhat lacking; however, there are no reports on the water quality of Lake Tonle Sap. In this area of rapid development, it is important to describe the present physical environment.

One characteristic of the catchment environment is that many people are concentrated in the northern part of the lake (Save Cambodia's Wildlife 2006: 56-84). Social infrastructures such as sewers are not provided to these residences, and the influence of human activities may have a large influence on the water quality. From the viewpoint of both informed water resource management and hydrological management, fundamental data on the physicochemical characteristics are required; however, current scientific data are limited. The water quality in Tonle Sap Lake is presumed to result from a mixture of water in the basin that is not high in water quality in the upstream region and backward water from the Mekong River. Furthermore, it is necessary to consider the influences of human activities.

The purpose of this study is to determine the spatial differences in the water quality of the largest freshwater lake in Southeast Asia. Furthermore, this study aims to evaluate the changes in the water quality properties of Lake Tonle Sap as affected by seasonal differences in the lake water volume, inflow sources, and human activities.

\section{Study Area}

Situated in central Cambodia, Lake Tonle Sap is the largest freshwater lake in Southeast Asia. It is connected to the Mekong River via the Tonle Sap River, and these two rivers join at the Chaktomuk Junction in Phnom Penh (Figure 1). Cambodia is subject to the Asian tropical monsoon, with distinct dry and rainy seasons. In each rainy season, the water level in the Mekong River rises, which triggers a reverse water flow from the Tonle Sap River into Lake Tonle Sap. While several rivers flow into Lake Tonle Sap, all of these, except the Mongkol Borei, Sen, and Siem Reap Rivers, cease to flow in the dry season. Figure 1 shows a map of the lake basin, which is presented at its smallest size (in the dry season). The size of Lake Tonle Sap varies from approximately $160 \mathrm{~km}$ long and $35 \mathrm{~km}$ wide during the dry season to $250 \mathrm{~km}$ long and $100 \mathrm{~km}$ wide at the height of flooding in the rainy season. The topological basin of the lake was formed approximately 5,500 years ago (Tsukawaki et al. 1994). It is usually illustrated (e.g., in atlases) in its dry-season configuration, with a surface area of approximately $2,400 \mathrm{~km}^{2}$. In the rainy season, however, the water level rises by $6-10 \mathrm{~m}$ and the surface area varies from $10,000 \mathrm{~km}^{2}$ to $20,000 \mathrm{~km}^{2}$ (Tanaka et al. 2003). It is notable that Lake Tonle Sap experiences the world's largest changes in surface area and water level of all the important lakes in the world that have large fluctuations in surface area and water depth.

According to Charles (1982), there are 46 large lakes in tropical and subtropical regions between the latitudes of $30^{\circ} \mathrm{N}$ and $30^{\circ} \mathrm{S}$. In comparison to Europe and America, there are few large lakes in Southeast Asia, with only three lakes of substantial size: Lake Tonle Sap (Cambodia), the Luang Sea (Thailand), and Lake Toba (Indonesia). In the rainy season, the total surface area of Lake Tonle Sap is ranked 14th in the world. This expansion in surface area is caused by a large inflow from the Mekong River, together with local rainfall. Approximately $70 \%$ of Lake Tonle Sap's water originates from the Mekong River, whereas approximately $30 \%$ arises from its own catchments and tributaries (Hori 1996). Lake Tonle Sap and its floodplain ecosystem are estimated to retain more than $80 \%$ of the sediments they receive from the Mekong River and its tributaries. Studies of sedimentation have shown that the net sedimentation rate in Lake Tonle Sap proper has been in the range of $0.10-0.16 \mathrm{~mm}$ year $^{-1}$ since the connection between the Mekong River and Lake Tonle Sap was established approximately 5,500 years ago (Tsukawaki 1997).

Air temperatures remain fairly uniform at approximately $25^{\circ} \mathrm{C}$ in the Tonle Sap Basin (Asian Development Bank 2005). According to Okumura et al. (2005), in the dry season, the air temperature in Siem Reap City (see Figure 1) in 2005 ranged from $21.0^{\circ} \mathrm{C}$ to $38.0^{\circ} \mathrm{C}$. In addition, the highest maximum temperatures, namely, $30.0-38.0^{\circ} \mathrm{C}$, were observed in March and April, and the lowest temperatures were recorded between November and the following February.

\section{Method and Materials}

\section{Sampling}

Field surveys of selected physical and chemical properties were undertaken in Lake Tonle Sap and several associated rivers between November 2004 and December 2005. Figure 2 shows the whole sampling locations. Two transverse survey lines in the NE-SW (N1-N10) and $\mathrm{N}-\mathrm{S}$ (S1-S10) directions were selected in the northern 


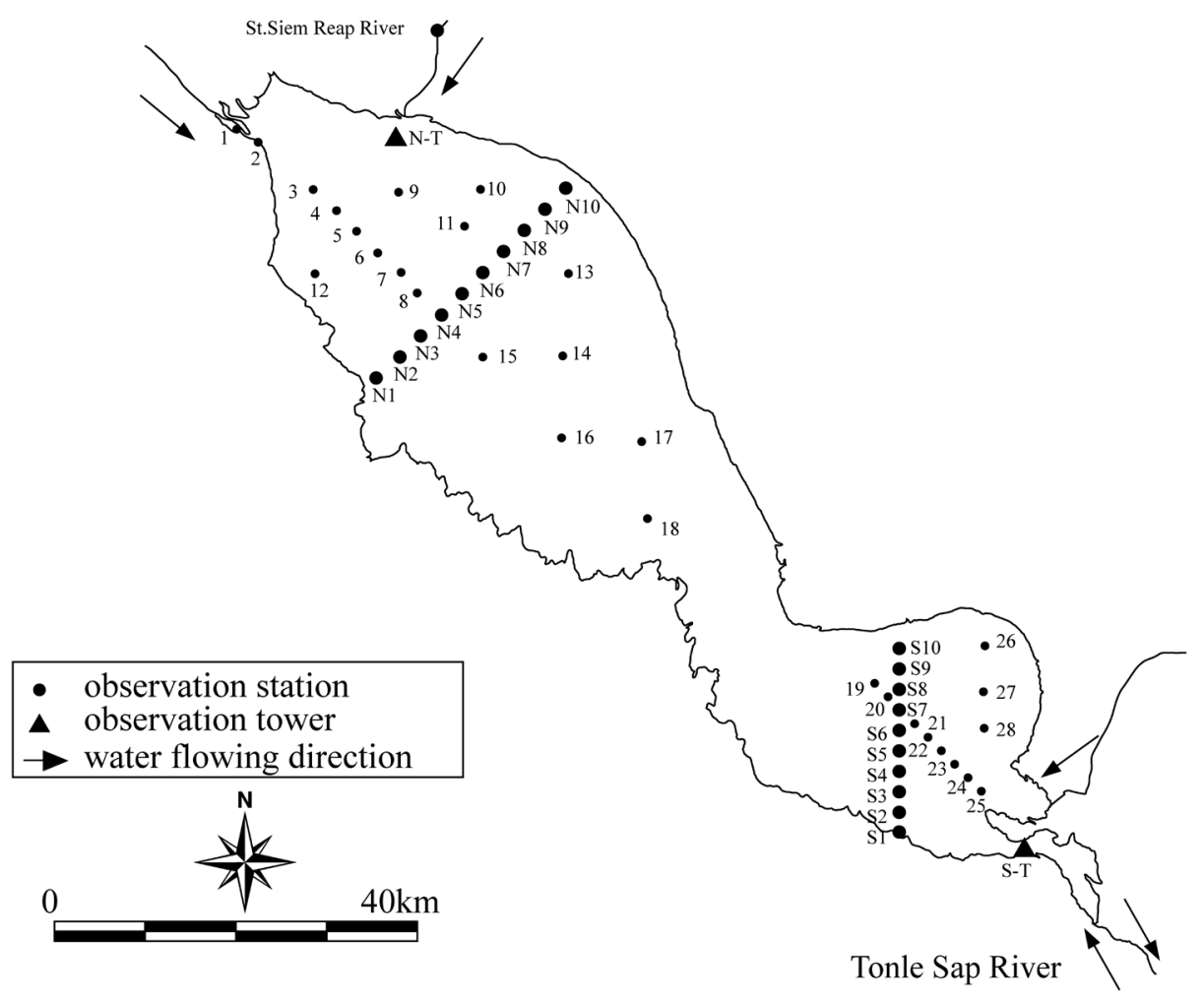

Figure 2. Sampling sites in Lake Tonle Sap (redrawn from Oyagi et al. 2009).

and southern parts of the lake. In the river areas, a site at Phnom Penh, Chaktomuk junktion, where the Tonle Sap River joins the Mekong River, and a site at Siem Reap were selected (Figure 1). The N-T and S-T stations were observation towers of the Ministry of Meteorology and Water Resources, Kingdom of Cambodia. Other sites were selected in the main body of the lake to determine the distribution of the physicochemical characteristics in the lake.

The vast range of movement involved in the survey required an extended period of observation and therefore involved daily variations, which were collected using the observation towers (N-T and $\mathrm{S}-\mathrm{T})$ as fixed points. Because large daily changes were not observed at these points, it can be assumed that the data for each sampling location indicates the seasonal water quality.

To determine the seasonal differences between the dry and rainy periods at each site, water samples of the surface were collected in December 2004 and March, May, August, and December 2005. In addition, water from the Siem Reap River, the Tonle Sap River, and the Mekong River was sampled in each period.

\section{Analysis}

At each site, the following measurements were made using a multi-parameter water quality profiler (JFE Advantech Co., Ltd. AAQ 1183 and Rinko Profiler): a vertical profile of the water temperature $\left({ }^{\circ} \mathrm{C}\right)$, the electri- cal conductivity and the depth of the water. Furthermore, the concentrations of major anions $\left(\mathrm{Cl}^{-}, \mathrm{SO}_{4}^{2-}, \mathrm{NO}_{2}^{-}\right.$, $\mathrm{NO}_{3}^{-}$, and $\left.\mathrm{PO}_{4}^{3-}\right)$ and major cations $\left(\mathrm{Na}^{+}, \mathrm{K}^{+}, \mathrm{Ca}^{2+}, \mathrm{Mg}^{2+}\right.$, and $\mathrm{NH}_{4}^{+}$) were measured via liquid chromatography in the laboratory (APHA-AWWA-WEF 1989: 2-35-2-39, 4-1-4-6). The $\mathrm{HCO}_{3}^{-}$concentration was determined using alkalinity titration with $\mathrm{N} / 50 \mathrm{H}_{2} \mathrm{SO}_{4}$. The differences in the water quality balance were $\pm 0.2 \mathrm{meq} \mathrm{L}^{-1}$, and all samples had an anion sum of $3.0 \mathrm{meq} \mathrm{L}^{-1}$.

The water level and temperature were recorded at the observation towers (N-T and S-T) from November 2004 to May 2005 using an automated meter (JFE Advantech Co., Ltd. Compact-TD). Precipitation was recorded in Siem Reap City using a weather station manufactured by Davis Instruments, Inc. (Vantage Pro) and in Kampong Chhnang City using a recorder manufactured by Onset Corp. During periods when the water level in Lake Tonle Sap was not recorded in the present study, continuous data were obtained from the Department of Hydrology and River Works of Cambodia and the National Institute for Rural Engineering of Japan.

\section{Results}

\section{Changes in the water level}

Figure 3 shows the variations in the daily precipitation between 2004 and 2006 observed at Siem Reap and Kompong Chhnang and the changes in the water level 


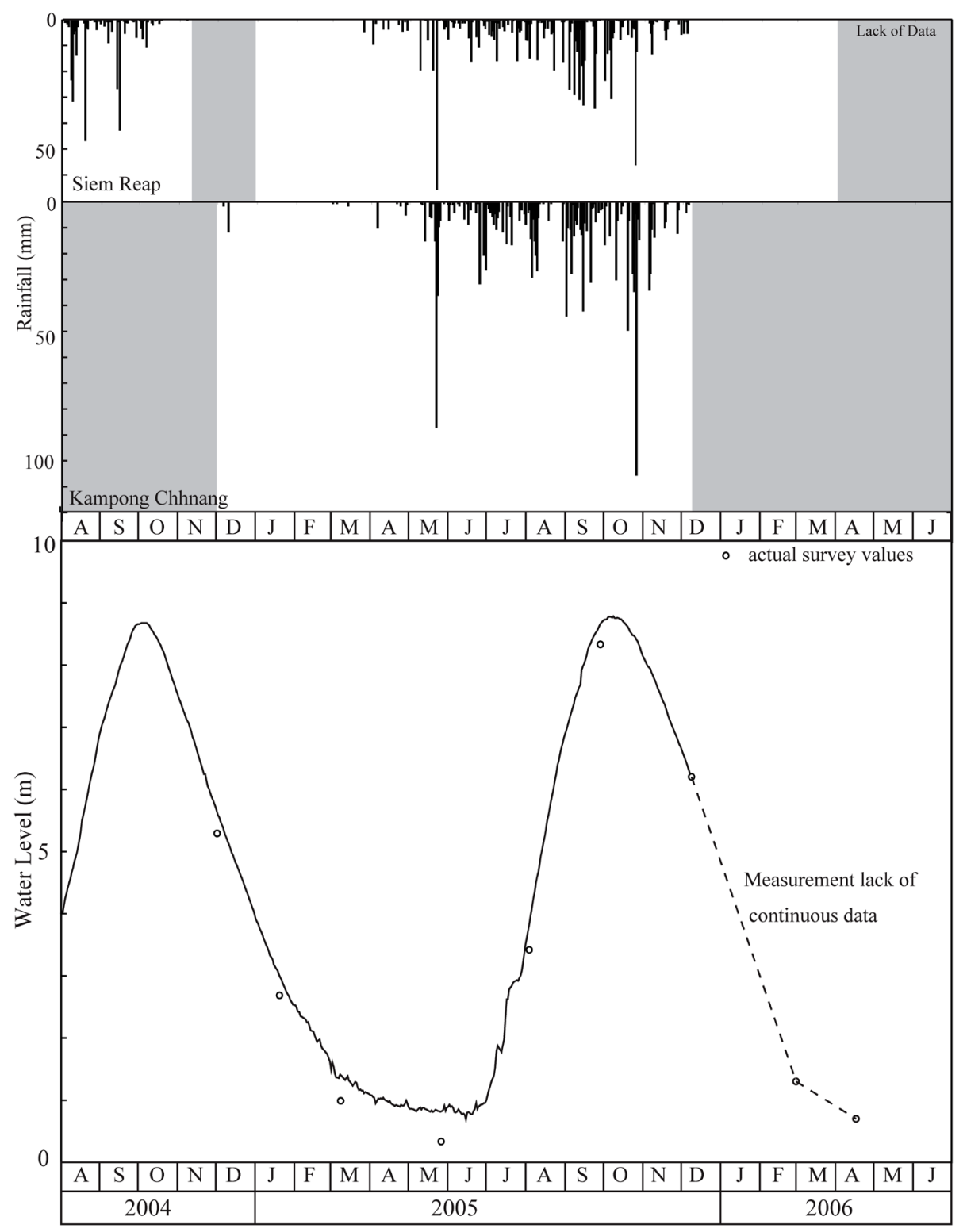

Figure 3. Daily precipitation and lake water level in Tonle Sap from August 2004 to August 2006.

Data of water level in the northern observation tower was obtained from the Department of Hydrology and River Works of Cambodia and the National Institute for Rural Engineering of Japan. The mark of open circle indicates actual survey values of water depth.

at the observation tower in the northern area of Lake Tonle Sap. The total annual precipitation in 2005 was $1,304 \mathrm{~mm}$ at Kompong Chhnang and $937 \mathrm{~mm}$ at Siem Reap. Two distinct periods were observed: a rainy season between May and October and a dry season between November and April. In the rainy season, the total precipitation at Kompong Chhnang and Siem Reap reached $1,278 \mathrm{~mm}$ and $868 \mathrm{~mm}$, respectively; this figure represents $92-98 \%$ of the annual precipitation. Annual rainfall in Cambodia was recorded as being between $1,000 \mathrm{~mm}$ per year and $1,900 \mathrm{~mm}$ per year from 1954 to 1966 and between $1,200 \mathrm{~mm}$ per year and $1,800 \mathrm{~mm}$ per year from 1966 to 1993 (MRCS/WUP-FIN 2002).

The precipitation in 2005 was lower than these earlier observations. Higher precipitation in the rainy season leads to higher water levels at Lake Tonle Sap. The maximum-recorded depths of the lake in October in 2004 and 2005 were $8.7 \mathrm{~m}$ and $8.8 \mathrm{~m}$, respectively. The rise in the water level was calculated to be an average of $7.5 \mathrm{~cm}$ per day (with a maximum of $32.5 \mathrm{~cm}$ per day) in 2005 . The water level in the lake begins to decrease when the dry season starts, and the minimum depth recorded was $0.5 \mathrm{~m}$ in June 2005, according to the continuous data. Even though the value from the field survey was $0.3 \mathrm{~m}$ in May 2005 (Figure 3), because of the characteristics of the equipment used, the accuracy is low when the water level is low. Therefore, the water level is primarily discussed here on the basis of the continuous data. The mean rate of decline in the water level was calculated to be $5.0 \mathrm{~cm}$ per day (with a maximum of $13.0 \mathrm{~cm}$ per day) 


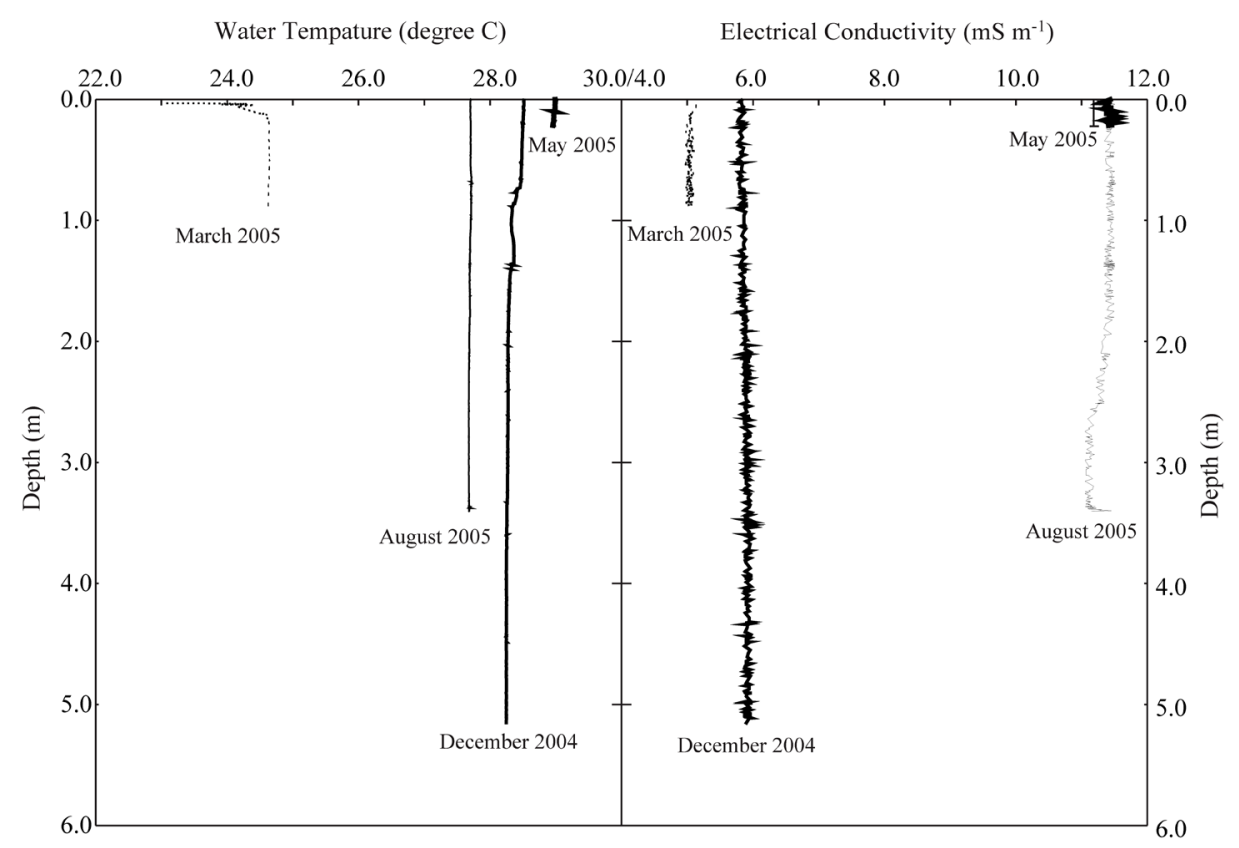

Figure 4. The vertical profile of electrical conductivity and water temperature in Lake Tonle Sap northern observation tower (N-T) (redrawn from Oyagi et al. 2009).

from November 2004 to March 2005 and $5.9 \mathrm{~cm}$ per day in 2006 .

\section{Water quality}

Vertical profiles of the water temperature and electrical conductivity were obtained at the northern observation tower (N-T) from 2004 to 2005 (Figure 4). The temperature of the surface water varied between $22^{\circ} \mathrm{C}$ and $30^{\circ} \mathrm{C}$ during the year, and the variations were nearly uniform from the surface to the bottom of the lake in each month except March, when the water temperature changed abruptly in the top $0.5 \mathrm{~m}$ of the water column.

The electrical conductivity ranged from $5 \mathrm{mS} \mathrm{m}^{-1}$ to $6 \mathrm{mS} \mathrm{m}^{-1}$ between December 2004 and March 2005 and from $11 \mathrm{mS} \mathrm{m}^{-1}$ to $12 \mathrm{mS} \mathrm{m}^{-1}$ between May and August 2005. These results confirm those of Okumura et al. (2005), who recorded the electrical conductivity and water temperature at the transverse survey stations from N1 to N10 in November 2003. In their study, the electrical conductivity was nearly uniform from the surface to the bottom of the lake.

The distributions of the inorganic parameters of the water quality are shown in Figure 5 as measured at the major locations from December 2004 to December 2005. In December 2004, the water level had already begun to decrease; however, the depth was still $5.5 \mathrm{~m}$. This was therefore considered to be part of the highwater-level season. The concentration of $\mathrm{Ca}^{2+}$ varied from $0.26 \mathrm{meq} \mathrm{L}^{-1}$ to $0.54 \mathrm{meqL}^{-1}$ (with a mean of $0.44 \mathrm{meqL}^{-1}$ ) in the north and from $0.32 \mathrm{meqL}^{-1}$ to $0.43 \mathrm{meq} \mathrm{L}^{-1}$ (with a mean of $\left.0.38 \mathrm{meqL}^{-1}\right)$ in the south. The concentration of $\mathrm{HCO}_{3}^{-}$varied from $0.49 \mathrm{meqL}^{-1}$ to $0.84 \mathrm{meqL}^{-1}$ (with a mean of $0.69 \mathrm{meq} \mathrm{L}^{-1}$ ) in the north and from $0.57 \mathrm{meq} \mathrm{L}^{-1}$ to $0.69 \mathrm{meqL}^{-1}$ (with a mean of $0.64 \mathrm{meq} \mathrm{L}^{-1}$ ) in the south. The ratios of $\mathrm{Ca}^{2+}$ and $\mathrm{HCO}_{3}^{-}$to total dissolved solids were $20.2-26.8 \%$ in the north and $34.2-41.1 \%$ in the south. In comparison, the equivalent ratios of $\mathrm{Ca}^{2+}$ and $\mathrm{HCO}_{3}^{-}$in the Mekong River reached 29.6\% and 39.2\%, respectively.

In March 2005, Sites 1-8 and 21-25 corresponded to the long axis of the lake in the NW-SE direction (Figure 5). During this period, the water level reached a depth of $1.0 \mathrm{~m}$. The concentration of $\mathrm{Ca}^{2+}$ varied from $0.07 \mathrm{meq} \mathrm{L}^{-1}$ to $0.39 \mathrm{meq} \mathrm{L}^{-1}$ (with a mean of $0.27 \mathrm{meq}^{-1}$ ) in the north $(\mathrm{N}-\mathrm{T}, \mathrm{N} 1-\mathrm{N} 10$, and Sites $1-8)$ and from $0.13 \mathrm{meq}^{-1}$ to $0.37 \mathrm{meq} \mathrm{L}^{-1}$ (with a mean of $0.28 \mathrm{meq} \mathrm{L}^{-1}$ ) in the south (S-T, S1-S10, and Sites 21-25). The concentration of $\mathrm{HCO}_{3}^{-}$varied from $0.26 \mathrm{meqL} \mathrm{L}^{-1}$ to $0.72 \mathrm{meqL}^{-1}$ (with a mean of $\left.0.69 \mathrm{meqL}^{-1}\right)$ in the north and from $0.25 \mathrm{meq} \mathrm{L}^{-1}$ to $0.66 \mathrm{meqL}^{-1}$ (with a mean of $0.64 \mathrm{meq} \mathrm{L}^{-1}$ ) in the south. The ratios of $\mathrm{Ca}^{2+}$ and $\mathrm{HCO}_{3}^{-}$to total dissolved solids were $6.1-20.0 \%$ in the north and $25.4-36.9 \%$ in the south. In comparison to the foreshore areas (Sites N-T, $\mathrm{N} 1, \mathrm{~N} 10$, and 2-4), the ratio of $\mathrm{Ca}^{2+}$ was low (6.1-16.5\%) and the ratio of $\mathrm{Na}^{+}$was high $(21.3-26.6 \%)$ in the other northern areas.

By May 2005, the water level had stopped decreasing and had reached a depth of $0.3 \mathrm{~m}$, which was the lowest water level of the year (Figure 3). Some observation points were added in the central part of the lake 


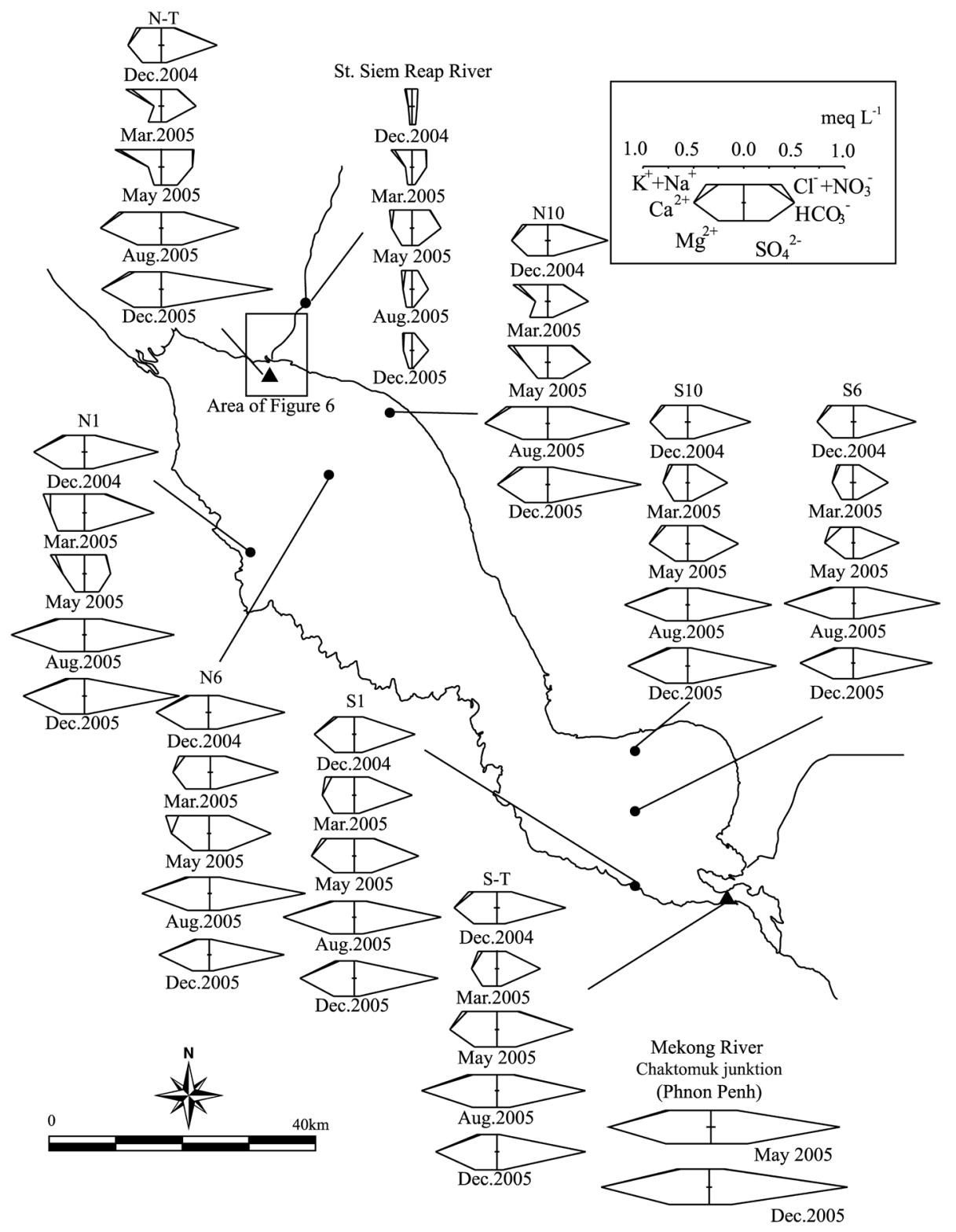

Figure 5. Seasonal change in water quality in Lake Tonle Sap, expressed as a Stiff diagram.

(Sites 3-18). The concentration of $\mathrm{Ca}^{2+}$ varied from $0.48 \mathrm{meq} \mathrm{L}^{-1}$ to $0.74 \mathrm{meq} \mathrm{L}^{-1}$ (with a mean of $0.66 \mathrm{meq} \mathrm{L}^{-1}$ ) in the north and from $0.31 \mathrm{meqL}^{-1}$ to $0.83 \mathrm{meq} \mathrm{L}^{-1}$ (with a mean of $0.61 \mathrm{meqL}^{-1}$ ) in the south. The concentration of $\mathrm{HCO}_{3}^{-}$ranged from $0.70 \mathrm{meqL}^{-1}$ to $1.01 \mathrm{meq} \mathrm{L}^{-1}$ (with a mean of $0.87 \mathrm{meqL}^{-1}$ ) in the north and from $0.50 \mathrm{meq} \mathrm{L}^{-1}$ to $1.15 \mathrm{meq} \mathrm{L}^{-1}$ (with a mean of $0.82 \mathrm{meq} \mathrm{L}^{-1}$ ) in the south. The ratios of $\mathrm{Ca}^{2+}$ and $\mathrm{HCO}_{3}^{-}$to the total dissolved solids ranged from $7.9 \%$ to $25.8 \%$ in the north and from $11.1 \%$ to $38.7 \%$ in the south. In comparison to the foreshore areas (Sites N-T, N2, N3, N8-N10, and 2-4), the ratios of $\mathrm{Ca}^{2+}, \mathrm{Na}^{+}, \mathrm{Cl}^{-}$, and $\mathrm{HCO}_{3}^{-}$to the total dissolved solids varied from $7.9 \%$ to $18.6 \%$, from $18.6 \%$ to $31.2 \%$, from $11.9 \%$ to $16.6 \%$, and from $18.3 \%$ to $29.4 \%$, respectively, in the other northern areas. The corresponding ratios in the Mekong River reached 21.5\%, 14.2\%,
$9.6 \%$, and $31.2 \%$, respectively.

In August 2005, the rainy season had caused water to flow from the Mekong River toward Lake Tonle Sap and the water level in the lake had begun to increase to a water depth of $3.4 \mathrm{~m}$. The concentration of $\mathrm{Ca}^{2+}$ ranged from $0.56 \mathrm{meqL}^{-1}$ to $0.74 \mathrm{meqL}^{-1}$ (with a mean of $0.67 \mathrm{meq} \mathrm{L}^{-1}$ ) in the north and from $0.43 \mathrm{meqL}^{-1}$ to $0.73 \mathrm{meq} \mathrm{L}^{-1}$ (with a mean of $0.65 \mathrm{meq} \mathrm{L}^{-1}$ ) in the south. The concentration of $\mathrm{HCO}_{3}^{-}$ranged from $0.72 \mathrm{meqL}^{-1}$ to $0.92 \mathrm{meq} \mathrm{L}^{-1}$ (with a mean of $0.89 \mathrm{meqL}^{-1}$ ) in the north and from $0.64 \mathrm{meqL}^{-1}$ to $0.92 \mathrm{meqL}^{-1}$ (with a mean of 0.83 meq $\left.\mathrm{L}^{-1}\right)$ in the south. The ratios of $\mathrm{Ca}^{2+}$ and $\mathrm{HCO}_{3}^{-}$ to the total dissolved solids ranged from $22.1 \%$ to $31.5 \%$ and from $30.0 \%$ to $44.7 \%$, respectively. In comparison to the lake water, the ratios of $\mathrm{Ca}^{2+}$ and $\mathrm{HCO}_{3}^{-}$in the Mekong River reached $32.0 \%$ and $43.3 \%$, respectively. 


\section{Discussion}

\section{Seasonal changes in the water quality}

The characteristics of Lake Tonle Sap clearly differ between the rainy and dry seasons. Each seasonal phase results in changes not only in the water level but also in the composition and distribution of the parameters of the water quality. In the present study, the parameters of the water quality at all sites were classified into three types: $\mathrm{Ca}-\mathrm{HCO}_{3}, \mathrm{Na} / \mathrm{Ca}-\mathrm{HCO}_{3}$, and $\mathrm{Na}-\mathrm{HCO}_{3}$. These types are comprised of the dominant ions $\mathrm{Ca}^{2+}, \mathrm{Na}^{+}+\mathrm{K}^{+}, \mathrm{Mg}^{2+}$, $\mathrm{Cl}^{-}+\mathrm{NO}_{3}^{-}, \mathrm{HCO}_{3}^{-}$, and $\mathrm{SO}_{4}^{2-}$.

The $\mathrm{Ca}-\mathrm{HCO}_{3}$ type at all sites included $\mathrm{Ca}^{2+}$ as more than $45 \%$ of the total cations and $\mathrm{HCO}_{3}^{-}$as more than $60 \%$ of the total anions. This type was uniform across all sites when the water level was high, e.g., in December 2004 and August 2005. This is because, when the water level is high, the water quality of the lake is influenced by the water entering Lake Tonle Sap from the Mekong River. The lake water therefore displayed a similar water composition to that of the Mekong River (Figure 5). Furthermore, the vertical profiles of the water temperature and electrical conductivity and the distribution of water quality indicated that the lake water was largely mixed at this time (Figure 4). Moreover, Hori (1996) reported that the distribution of the parameters of the water quality was nearly uniform across the Mekong River Basin from Yunnan in China to Phnom Penh in Cambodia. The average ratios of $\mathrm{Ca}^{2+}$ and $\mathrm{HCO}_{3}^{-}$of the total dissolved solids at Phnom Penh from 1993 to 1995 were approximately $40 \%$ and $39 \%$, respectively (Hori 1996). The water composition of the lake became identical to that of the river water as the average ratios of $\mathrm{Ca}^{2+}+\mathrm{Mg}^{2+}$ and $\mathrm{HCO}_{3}^{-}$reached $37.2 \%$, that of $\mathrm{Ca}^{2+}$ ranged from $20.2 \%$ to $31.1 \%$, and that of $\mathrm{Mg}^{2+}$ ranged from 9.0\% to $12.4 \%$ in Lake Tonle Sap in December 2004 and August 2005 (Figure 5). Therefore, the water quality in the lake appeared to closely reflect the water quality in the Mekong River, even though there was a difference in the concentration.

The $\mathrm{Na} / \mathrm{Ca}-\mathrm{HCO}_{3}$ and $\mathrm{Na}-\mathrm{HCO}_{3}$ types appeared in the foreshore areas when the water level was low, e.g., in March and May 2005 (Figure 5), even though the $\mathrm{Ca}-\mathrm{HCO}_{3}$ type was distributed in the central and southern parts of the lake in these periods. The $\mathrm{Na} / \mathrm{Ca}-\mathrm{HCO}_{3}$ type has a ratio of $\mathrm{Ca}^{2+}$ and $\mathrm{Na}^{+}$between $30 \%$ and $40 \%$ of the total cations and included $\mathrm{HCO}_{3}^{-}$as more than $60 \%$ of the total anions. The $\mathrm{Na}-\mathrm{HCO}_{3}$ type has a ratio of $\mathrm{Na}^{+}$of more than $45 \%$ of the total cations and included $\mathrm{HCO}_{3}^{-}$as more than $60 \%$ of the total anions. The backflow water from the Mekong River flows out of Lake Tonle Sap after the rainy season, and the lake then sources water from inflowing rivers (e.g., the Siem Reap River) during the dry season. During the low-water-level period, the lake derives its water quality characteristics from these sources. Evidence of this can be seen in the increase in the ratio of $\mathrm{Na}^{+}+\mathrm{K}^{+}$from the foreshore toward the central part of the lake.

Differences in the characteristics of the water quality divide the northern and southern parts of the lake into two areas. In the northern part, the dominant water quality was observed to be characterized by the $\mathrm{Ca}-\mathrm{HCO}_{3}$, $\mathrm{Na} / \mathrm{Ca}-\mathrm{HCO}_{3}$, and $\mathrm{Na}-\mathrm{HCO}_{3}$ types in March and May 2005. However, no difference in water quality type was observed in the southern area.

Table 1 shows the electrical conductivity and the water quality of the inflowing water from the Siem Reap River and water at the observation towers $(\mathrm{N}-\mathrm{T}$ and $\mathrm{S}-\mathrm{T})$. The electrical conductivity of both the lake and the inflowing Siem Reap River water displayed high values in May and August (Figure 4). Moreover, dissolved solids in the lake water exhibited high values in the low-water-level period in May; for example, the concentrations of $\mathrm{Na}^{+}$and $\mathrm{Cl}^{-}$at the observation tower at the northern part of the lake ranged from $3.4 \mathrm{mg} \mathrm{L}^{-1}$ to $9.5 \mathrm{mg} \mathrm{L}^{-1}\left(0.15-0.41 \mathrm{meq} \mathrm{L}^{-1}\right)$ and from $2.8 \mathrm{mg} \mathrm{L}^{-1}$ to $9.6 \mathrm{mg} \mathrm{L}^{-1}\left(0.08-0.27 \mathrm{meqL}^{-1}\right)$, respectively. This difference was primarily observed in the northern part of the lake, and a clear shift in values was not seen in the high ratio of $\mathrm{Na}^{+}$and $\mathrm{Cl}^{-}$in the dry season at the southern observation tower. A comparison of the water quality between March and May (under low-waterlevel conditions) with that in December indicates that the changes in composition at the northern observation tower are typical.

The $\mathrm{NH}_{4}^{+}$and $\mathrm{NO}_{3}^{-}$levels were found to be relatively high in the northern part of the lake. However, the numerical values were below the environmental standard values for WHO (World Health Organization) and the anthropogenic effects are not clear from the behavior of the nitric acid. However, there was a clear artificial influence on the $\mathrm{Na}^{+}$and $\mathrm{Cl}^{-}$concentrations.

The water quality in the Siem Reap River flowing into the lake is also greatly artificially affected by the presence of $\mathrm{Cl}^{-}$and $\mathrm{Na}^{+}$, and it has been pointed out that the detected amount of nitrogen- and phosphorus-containing nutrients is small (Oyagi et al. 2014). For this reason, it is necessary to determine the nitrogen circulation of the ecosystem in this tropical area. This paper advances the argument that the $\mathrm{Na}^{+}$and $\mathrm{Cl}^{-}$concentrations give rise to artificial effects. 


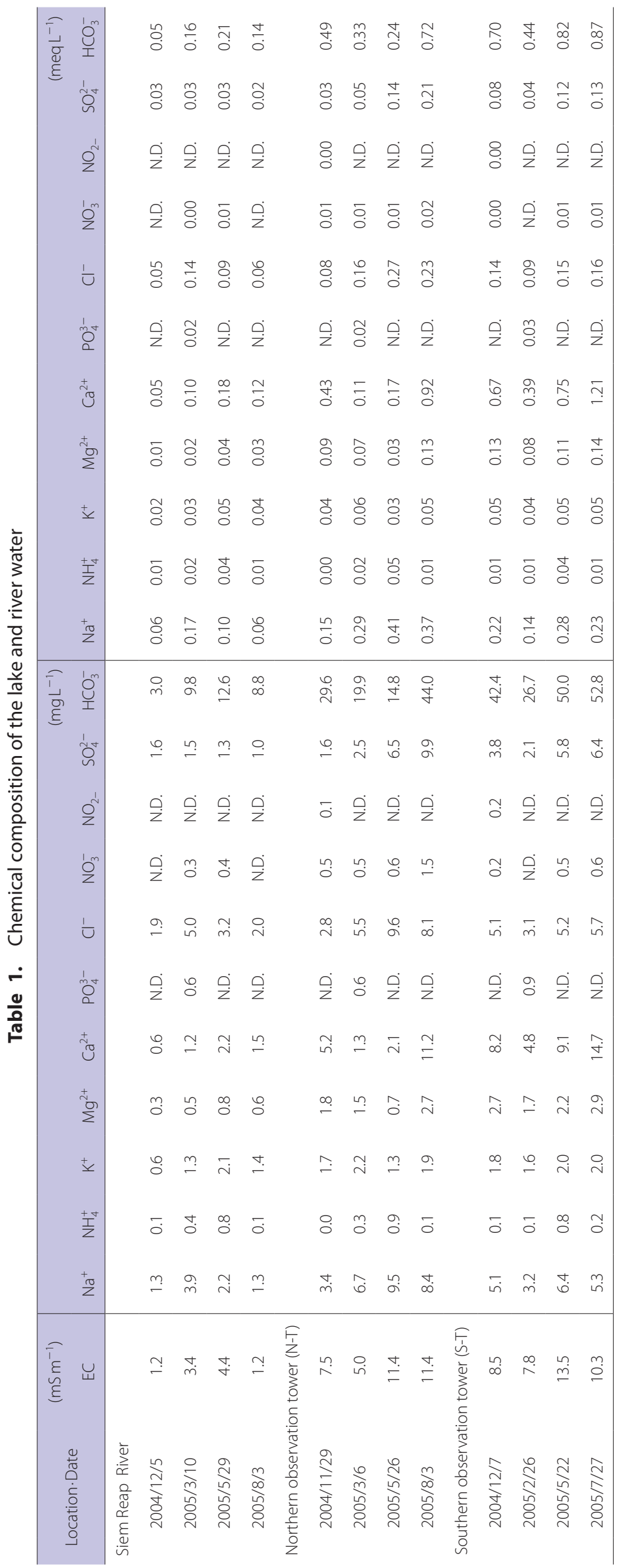




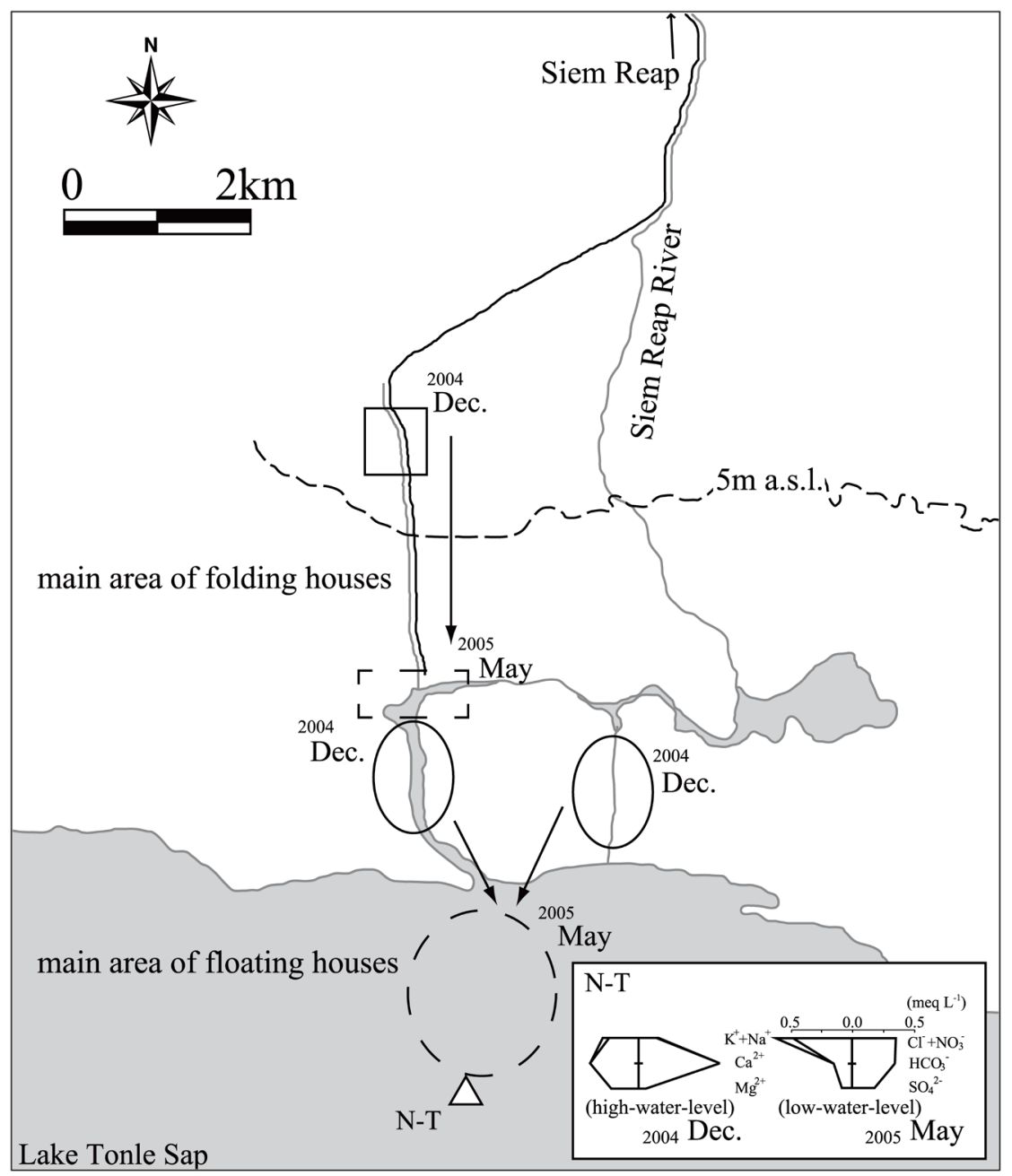

Figure 6. Movement of folding and floating houses around the river mouth of Siem Reap between December 2004, highwater-level period, and May 2005, low-water-level period.

\section{Seasonal changes in the human activity on the northern foreshore}

Significant locations for this part of the study are the mouth of the Siem Reap River and the northern foreshore area. Human activities contribute to increasing the concentrations of $\mathrm{Na}^{+}$and $\mathrm{Cl}^{-}$in low-water-level periods. Even though an increase in $\mathrm{Na}^{+}$and $\mathrm{Cl}^{-}$is often caused by the influence of seawater, the position of Lake Tonle Sap in central Cambodia excludes marine influences. Furthermore, the values of electrical conductivity observed in the lake were not typical of seawater. According to Kasai (2003), the population in the region of Lake Tonle Sap is approximately 1.2 million people. Moreover, the population in the area that is flooded for more than five days a year is approximately 340,000 people (estimated from 1995 data). Their accommodation consists of folding and floating houses. Many of these people make a living by fishing in Lake Tonle Sap, with approximately 170 villages and 14,000 households being directly dependent on fishery for their livelihood. According to Save Cambodia's Wildlife (2006: 56-84), the residential houses are concentrated in the northern basin area of Lake Tonle Sap. The range where the water quality composition greatly differs is primarily in the northern part of the lake and is especially prominent near $\mathrm{N}-\mathrm{T}$ (Figure 5). Therefore, it is thought that the increase in the $\mathrm{Na}^{+}$and $\mathrm{Cl}^{-}$contents was caused by anthropogenic contamination (Hannya and Ogura 1995). That is, the changes in the water quality were caused by people living on the banks of the lake. The tendency of the changes in the composition at the northern observation tower is a typical case. This difference was primarily recognized in the northern parts of the lake as a clear shift in the concentrations of $\mathrm{Na}^{+}$and $\mathrm{Cl}^{-}$at the northern tower; this shift was not observed at the southern observation tower. The water quality composition of S-T is relatively similar to the water quality of the Mekong River throughout the year.

Figure 6 shows the movement of the folding and floating houses in the village of Chong Khneas at the northern part of the lake (near the observation tower) in the 2005 dry season. In situ interview has estimated that there 
Table 2. The estimation of $\mathrm{Cl}^{-}$in the mixing of the lake and basin water

\begin{tabular}{|c|c|c|c|c|c|c|}
\hline & & & & The concentration of & & \\
\hline & & $\begin{array}{c}\text { Water level (N-T) } \\
(\mathrm{m})\end{array}$ & $\begin{array}{c}\mathrm{S}-\mathrm{T} \\
\left(\mathrm{mg} \mathrm{L}^{-1}\right)\end{array}$ & $\begin{array}{l}\text { The center area of floating houses* } \\
\qquad\left(\mathrm{mg} \mathrm{L}^{-1}\right)\end{array}$ & $\begin{array}{c}\mathrm{N}-\mathrm{T} \\
\left(\mathrm{mg} \mathrm{L}^{-1}\right)\end{array}$ & $\begin{array}{l}\text { Estimation } \\
\left(\mathrm{mg} \mathrm{L}^{-1}\right)\end{array}$ \\
\hline High-water-level & 2004. Dec & 5.7 & 5.1 & 3.5 & 2.8 & 4.0 \\
\hline Low-water-level & 2005. May & 0.8 & 5.8 & 17.0 & 9.6 & 13.6 \\
\hline
\end{tabular}

*Shown in Figure 6.

are 1,300 houses in the area near the mouth of the Siem Reap River, which contains approximately $10 \%$ of the total number of villages around the lake. Moreover, this area attracts many people such as travelers at certain times of the year. In addition, it is thought that substantial amounts of material flow from the sightseeing areas of the Angkor monuments in Siem Reap City, which is located upstream, and the sewerage system in these areas is incomplete. Therefore, it is likely that the changes in the water quality are affected by the modes of settlement around the lake, such as folding houses and floating villages.

It is thought that the quality of water formed in the whole lake is based on the lake water passing through the S-T point from the Mekong River. According to Hori (1996), the inflow amount from the Mekong River to Tonle Sap Lake is estimated to be 60 billion $\mathrm{m}^{3}$ and the outflow is estimated to be 85 billion $\mathrm{m}^{3}$. In other words, it is estimated that approximately $30 \%$ of the water is an influx from the basin of Lake Tonle Sap. Table 2 shows an estimate of the effects of the local human activity around the area of N-T. The concentration of $\mathrm{Cl}^{-}$at $\mathrm{N}-\mathrm{T}$ in the period of high water level, $7.0 \mathrm{~m}$, in December 2004 was $2.8 \mathrm{mg} \mathrm{L}^{-1}$, and the concentration of $\mathrm{Cl}^{-}$in the densely populated areas, the central area of floating houses, of the lake area during this period was $3.5 \mathrm{mg}$ $\mathrm{L}^{-1}$. Conversely, the concentration of $\mathrm{Cl}^{-}$at $\mathrm{N}-\mathrm{T}$ in the period of low water level, $0.8 \mathrm{~m}$, in May 2005 was $9.6 \mathrm{mg}$ $\mathrm{L}^{-1}$ and the concentration of $\mathrm{Cl}^{-}$in the densely populated areas of the lake area during this period was $17.0 \mathrm{mg} \mathrm{L}^{-1}$. However, the concentration of $\mathrm{Cl}^{-}$at $\mathrm{S}-\mathrm{T}$ was $5.1 \mathrm{mg} \mathrm{L}^{-1}$ and $5.8 \mathrm{mg} \mathrm{L}^{-1}$, respectively. Assuming that the ratio of water supplied from the Mekong River and the catchment area was 7:3 (Hori 1996), it is estimated that the effects on the water quality at the center of floating houses are $4.0 \mathrm{mg} \mathrm{L}^{-1}$ in the high-water-level period and $13.6 \mathrm{mg}$ $\mathrm{L}^{-1}$ in the low-water-level period. These values are close to those observed for N-T. Consequently, human pollution and household waste are concentrated near the area of the observation tower in the village on the foreshore. Furthermore, the situation worsens in the dry season, when the reduction in the water volume increases the concentrations of the total dissolved solids in the water. However, the water quality of the lake during the rainy season experiences little effect from human activity due to the reverse inflow from the Mekong River. The backward flow of the water acts to dilute the concentrations of pollutants in the high-water-level period.

\section{Relationship between the influences of human activities and the lake water mixing}

Changes in the water quality in the northern part of the foreshore area were deduced primarily from Figure 5. Figure 7 shows a Piper's key and triangular diagrams that illustrate the characteristics of the water quality of the lake. In Figure 7, the sites that did not display a significant difference during seasonal changes in the water composition included the southern observation tower (S-T). Therefore, Figure 7 shows the water composition at Sites N-T, S-T, N1, and N10 in the lake and at the Mekong and Siem Reap River sites. The water composition at the observation tower in the northern area, which is near the foreshore, was divided into two groups for each month: the low-water-level period and high-water-level period.

During the low-water-level period of the lake, i.e., March and May, the characteristics of the water quality show the influence of the tributaries; the water composition of the Siem Reap River differs from that of the Mekong River. According to the investigation of water quality in the low-water-level period, the $\mathrm{Na}-\mathrm{HCO}_{3}$ type was primarily recognized in the northern foreshore area, especially between March and May 2005. Of particular interest during the low-water-level period is the ratio of $\mathrm{Cl}^{-}$ions to the total dissolved solids. These results indicate that the changes in the lake water quality in the low-water-level periods are caused in part by an increase in the influence of anthropogenic contamination from mobile villages of floating and folding houses situated on the foreshore.

Conversely, in high-water-level periods (in August and December), the dominant composition for the water quality was the $\mathrm{Ca}-\mathrm{HCO}_{3}$ type. The water composition 


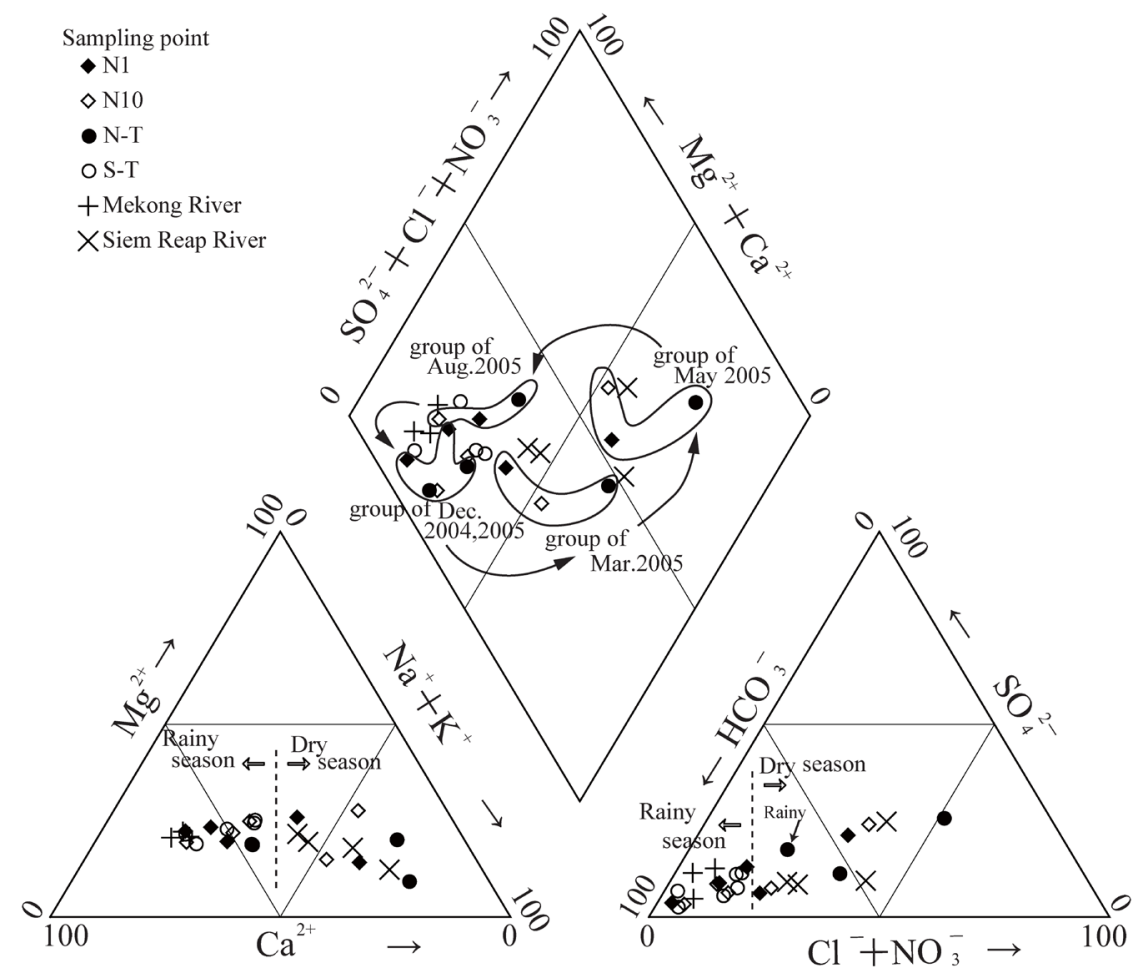

Figure 7. Piper's key and triangular diagrams showing the seasonal change in water quality of Lake Tonle Sap, the Siem Reap River and the Mekong River.

across all sites was similar to that of the Mekong River. Accordingly, the water quality of the lake is affected by the Mekong River water during high-water-level periods and the lake is not affected by local human activity during the rainy season. Therefore, the characteristics of the water quality of the lake can be divided into two types of contrasting features in the low- and high-water-level periods. It is conceivable that the characteristics of the water quality change with the seasons.

\section{Conclusions}

The characteristics of the water quality in Lake Tonle Sap were assessed in periods of both low and high water levels. The physicochemical characteristics were determined by the backward inflow of water from the Mekong River during the rainy season and an increase in discharge from inflowing tributaries, together with human activities, during the dry season. The results are summarized as follows.

1. The dominant water type in Lake Tonle Sap was the $\mathrm{Ca}-\mathrm{HCO}_{3}$ type. When investigating the water quality over a full year, the $\mathrm{Na}-\mathrm{HCO}_{3}$ type was primarily recognized in the foreshore area during the low-waterlevel period of March and May 2005. Typical annual characteristics of the water quality, such as the $\mathrm{Ca}-\mathrm{HCO}_{3}$ type in the high-water-level period and the
$\mathrm{Na}-\mathrm{HCO}_{3}$ type in the low-water-level period, were measured at the northern observation tower.

2. In Lake Tonle Sap, the floating and folding houses on the lake move with the seasonal changes in the water levels. The characteristics of the quality of the lake water in the low-water-level periods are caused in part by an increase in the influence of the discharge of the inflowing tributaries as a result of a decrease in the volume of the lake water.

3. In the dry season, the change in water quality is caused by human contamination from thousands of households on the shores of the northern part of the lake. In the rainy season, however, the water quality of the lake does not appear to be affected by local human activity but takes on the characteristics of the backward flowing water from the Mekong River.

This result was discussed based on the changes in the water quality in 2005. As mentioned earlier, because it has been estimated that the rainfall in this year was less than that in a normal year, a situation with artificial pollution is likely to be confirmed due to the decrease in the volume of the lake water. However, because there has been no change in the minimum water level in comparison to a normal year and the fluctuations in the water levels have not changed significantly, this can be considered to be a normal variation in the water quality. 


\section{Acknowledgements}

The authors would like to gratefully express their deep gratitude to Dr. K. Mori, Nihon University, for valuable advice on this work. Comments and help were also given by Mr. S. I. Monichoth, Department of Hydrology and River Works, Ministry of Meteorology and Water Resources, Kingdom of Cambodia and Dr. H. Peou, Deputy Director General, APSARA National Authority, Kingdom of Cambodia kindly cooperated with our survey. Much technical help was also given by members of EMSB, team of Evaluation of Mechanisms Sustaining the Biodiversity in Lake Tonle Sap, Cambodia, and EMSB-u32 Research Team of Tonle Sap. We also gratefully acknowledge Dr. T. Masumoto, National Institute for Rural Engineering of Japan, and Ms. K. Tsujimoto, Tokyo University, for allowing us to use their data. This research was supported by "Tonle Sap EMSB-u32 Programme: UNESCO MAB-IHP Joint Programme Ecological and Hydrological Research and Training for Young Scientist in Tonle Sap Biosphere Reserve, Cambodia: Research and Training for Young Scientists," Grant-in-Aid for International Scientific Research. It also was supported by MEXT/JSPS KAKENHI Grant Number JP 15405004, Grant-in-Aid for Scientific Research (B), 16H05617, Grant-in-Aid for Scientific Research (B), and 23701032, Grant-in-Aid for Young Scientists (B).

\section{References}

APHA-AWWA-WEF 1989. Standard methods for the examination of water and wastewater 17th ed. Washington D.C.: American Public Health Association.

Asian Development Bank 2005. Initial environmental examination report for Tonle Sap sustainable livelihoods project in Cambodia. Manila: Asian Development Bank.

Campbell, I. C., Poole, C., Giesen, W. and Valbo-Jorgensen, J. 2006. Species diversity and ecology of Tonle Sap Great Lake Cambodia. Aquatic Sciences 68: 355-373.

Charles, E. H. 1982. Large lakes of the world. Journal of Great Lakes Research 8: 379-412.

Hannya, T. and Ogura, N. 1995. Investigation method of water quality. Tokyo: Maruzen. (J)

Hori, H. 1996. The Mekong, environment and development. Tokyo: Kokon Shoin. (J)

Ishikawa, T., Oyagi, H., Ohtaka, A., Narita, T., Sim, I. and Tsukawaki, S. 2005. Primary production in Lake Tonle Sap. In Proceedings of the First International Symposium on Evaluation of Mechanisms Sustaining the Biodiversity in Lake Tonle Sap. ed. S. Tsukawaki, Y. Araki and H. Oyagi, 57-59. Phnom Penh: Ministry of Industry, Mines and Energy.
Kasai, T. 2003. Preliminary consideration about the environmental preservation of the Tonle Sap. Ritsumeikan International Affairs 21: 41-64. (J)

Lao, K. L. 1992. The inland water environment of the Angkor region-Preliminary survey of water quality-Renassance Culturelle du Cambodge. Sophia University Institute Asian Culture 6: 109-128.

Max, M. T. and Colette, S. 1990. Large lakes: Ecological structure and function. Berlin: Springer.

Mori, K. 1975. On the residence time of lake water viewed from the variation in concentration of dissolved constituents at Lake Suigetsu. Geographical Review of Japan 48: 63-71. (J)

MRCS/WUP-FIN 2002. Revised data report, water utilization program: Modelling of the flow regime and water quality of the Tonle Sap. Phnom Penh: Mekong River Commission/Finnish Environment Institute Consultancy Consortium.

Okumura, Y., Endoh, S., Darith, E. and Oyagi, H. 2005. Meteorological characteristics of Siem Reap City, Cambodia. In Proceedings of the First International Symposium on Evaluation of Mechanisms Sustaining the Biodiversity in Lake Tonle Sap. ed. S. Tsukawaki, Y. Araki and H. Oyagi, 79-81. Phnom Penh: Ministry of Industry, Mines and Energy.

Oyagi, H., Endoh, S., Okumura, Y., Tsukawaki, S. and Mori, K. 2009. Characteristics of water temperature in Lake Tonle Sap, Cambodia. In Proceedings of the Institute of Natural Sciences, Nihon University 44. ed. Institute of Natural Sciences, Nihon University, 167-176. Tokyo: Institute of Natural Science, Nihon University. (J)

Oyagi, H., Peou, H. and Tsukawaki, S. 2014. Characteristics of water quality in the Siem Reap River basin, Cambodia. In Proceedings of the Institute of Natural Sciences, Nihon University 49. ed. Institute of Natural Sciences, Nihon University, 103-114. Tokyo: Institute of Natural Science, Nihon University. (J)

Sarkkula, J., Koponen, J. and Kummu, M. 2005. Flood pulsing and productivity factors in Tonle Sap system. In Proceedings of the First International Symposium on Evaluation of Mechanisms Sustaining the Biodiversity in Lake Tonle Sap. ed. S. Tsukawaki, Y. Araki and H. Oyagi, 33-35. Phnom Penh: Ministry of Industry, Mines and Energy.

Save Cambodia's Wildlife 2006. The atlas of Cambodia, national poverty and environment maps. Cambodia: Danida.

Tanaka, M., Sugimura, T., Tanaka, S. and Tamai, N. 2003. Flooddrought cycle of Tonle Sap and Mekong Delta area observed by DMSP-SSM/I. International Journal of Remote Sensing 24: 1487-1504.

Tsukawaki, S. 1997. Lithological features of cored sediments from the northern part of the Tonle Sap Lake, Cambodia. In The International Conference on Stratigraphy and Tectonic Evolution of Southeast Asia and the South Pacific. ed. Phisit Dheeradilok, 232-239. Bangkok: GEOTHAI'97.

Tsukawaki, S., Okawara, M., Lao, K. L. and Tada, M. 1994. Preliminary study of sedimentation in Lake Tonle Sap, Cambodia. Journal of Geography (Chigaku Zasshi) 103: 623636. (J)

(J) written in Japanese 